\title{
Quality Improvement in Neurology 2020 Parkinson Disease Quality Measurement Set Update
}

Kelvin L. Chou, MD, Justin Martello, MD, Juliana Atem, MSN, APRN, Matt Elrod, DPT, Erin R. Foster, PhD, OTD, OTR/L, Karen Freshwater, PA-C, Steven A. Gunzler, MD, Hojoong Kim, MD, Abhimanyu Mahajan, MD, MHS, Harini Sarva, MD, Glenn T. Stebbins, PhD, Erin Lee, and Laurice Yang, MD, MHA

Neurology ${ }^{\circledR}$ 2021;97:239-245. doi:10.1212/WNL.0000000000012198

Parkinson disease (PD) is the second most common neurodegenerative disorder, after Alzheimer disease, ${ }^{1}$ and the number of individuals with PD worldwide more than doubled between 1990 and $2015 .^{2}$ In 2016, PD affected an estimated 6.1 million people globally. ${ }^{3}$ In the United States, an estimated 680,000 individuals $\geq 45$ years of age had PD in $2010 .{ }^{4}$ These numbers were projected to rise to 930,000 in 2020 and to reach $1,238,000$ by $2030 .{ }^{4}$ Both motor (rest tremor, bradykinesia, rigidity) and nonmotor (including but not limited to neuropsychiatric, autonomic, and sensory) symptoms of PD contribute to decreased quality of life ${ }^{5}$ and neurologic disability. ${ }^{3}$

Quality measures are becoming increasingly important for payment incentive programs, which insurance providers such as Medicare may use to adjust reimbursement (through either bonuses or penalties) on the basis of performance. The American Academy of Neurology (AAN) introduced the original PD Quality Measurement Set in 2010, ${ }^{6}$ which was the first Quality Measurement Set developed independently by the AAN. The PD measurement set underwent an update in 2015. ${ }^{7}$ Over the years, the AAN has developed Quality Measurement Sets for other neurologic subspecialties but also a universal set applicable to all patients with neurological disease. ${ }^{8}$ In this executive summary, we report the second update of the PD Quality Measurement Set, which retains important PD-specific measures and reduces overlap with the Universal Neurology Quality Measurement Set. The full measurement set document is available online (aan.com/siteassets/home-page/policy-and-guidelines/quality/quality-measures/movement-disorders/2020-parkinson-disease-measurement-set-final.pdf).

\section{Opportunities for Improvement}

Care from a trained neurologist improves outcomes in PD; individuals with PD who receive care from a neurologist are at lower risk for hospitalization ${ }^{9}$ and are less likely to end up in a skilled nursing facility. ${ }^{10}$ Yet up to $40 \%$ of individuals with PD in the United States do not see a neurologist, ${ }^{10}$ emphasizing the need for quality measures that can potentially improve the delivery of PD care. There is limited evidence regarding the use of existing PD quality measures. Using the 2010 PD Quality Measurement Set, Baek et al. ${ }^{11}$ reviewed the notes of 33 neurologists and found that movement disorders neurologists documented more measures $(4.7 \pm$ $2.86)$ than nonmovement neurologists $(3.3 \pm 1.97)$. Chart review at an academic movement disorders practice (University of Maryland) revealed a $68 \%$ documentation compliance rate across the 2010 AAN measures, although 4 measures had at least $90 \%$ compliance. ${ }^{12}$ Improving quality measure documentation requires special effort or investment in infrastructure. The movement disorders neurologists in the Baek et al. study used extensive templates to achieve better documentation, ${ }^{11}$ while the measures with the highest compliance rate in the Maryland study were due to established routine clinical protocols. ${ }^{12}$ The establishment of a comprehensive PD care clinic resulted in documentation of all 10 of the 2010 AAN PD quality

Correspondence

American Academy

of Neurology

quality@aan.com 
measures at an initial visit compared to documentation of only 5 measures with routine movement disorders specialty care. ${ }^{13}$ These studies demonstrate that gaps in care remain.

\section{Methods}

The AAN initiates review of quality measures periodically to determine whether an update is warranted. Through implementation of the PD quality measures in the Axon Registry and in the Medicare Quality Payment Program (QPP) MeritBased Incentive Payment System (MIPS) program, the AAN determined that an update was necessary to improve measure specifications for the PD quality Measurement Set.

Similar to previous iterations, the AAN formed a work group of key stakeholders focused on PD to participate in the update of this measurement set. Nominations for this work group were solicited from AAN membership, other physician and nonphysician associations with an interest in PD, and PD patient and caregiver organizations. Details of the full measure development process are available online (aan.com/siteassets/home-page/policy-and-guidelines/quality/quality-measures/how-measures-are-developed/19_qualitymeasuredevprocman_v304.pdf).

All work group members disclosed potential conflicts of interest and completed applications summarizing experiences and interests. The facilitators and chair independently selected members for the work group from the pool of qualified specialists and expert nominees. The selection of the 12member work group was based on the nominee's experience in performance measures, quality improvement, and clinical activities, with the goal of fielding a diverse, multidisciplinary group with broad representation in terms of practice type/ location, background, and clinical expertise.

The measure development process included the following: (1) performing an evidence-based literature search, (2) establishing a multidisciplinary work group adhering to the AAN conflict of interest policy, (3) drafting candidate measures and technical specifications, (4) convening the work group virtually to review candidate measures, (5) refining and discussing the candidate measures, (6) soliciting public comments on approved measures during a 30-day period, (7) refining the final measures according to input received during the public comment period and corresponding technical specifications, and (8) obtaining approvals from the work group, AAN Quality Measures Subcommittee, AAN Quality Committee, and American Academy of Neurology Institute Board of Directors.

The work group sought to develop evidence-based measures to support the delivery of high-quality care and to improve patient outcomes. The reliance on an evidence base to support the crafting of measures is based on criteria set forth by the AAN (see measure development process link provided earlier), although the work group acknowledges that there are limitations to evidence-based medicine. Guided by a medical librarian, the work group conducted a comprehensive literature search for guidelines, systematic reviews, meta-analyses, and quality improvement articles since 2015 (the date of the last measurement set update) on PubMed, PsychINFO, OVID Medline, BM reviews, and Embase. The key words used in the literature search are listed at the following link: aan.com/siteassets/home-page/policy-and-guidelines/quality/quality-measures/movement-disorders/literature-searchfor-pd-quality-measures.pdf. The literature search resulted in 3,745 abstracts relevant to the potential measures. AAN staff reviewed each abstract and eliminated duplicates and abstracts that were off topic. The work group examined the abstracts and identified 20 guidelines, systematic reviews, and meta-analyses that formed the core of the evidence base for the revisions to this measurement set. In addition to reviewing the measures from the 2015 update, work group members had the opportunity to submit new measure concepts for consideration. In updating this measurement set, the work group aimed to reduce the reporting burdens of the measures while upholding the quality of PD care. As part of this effort, the work group also tried to harmonize measures between this set and other AAN Quality Measurement Sets.

Over the course of several virtual meetings, a draft measurement set was developed and posted for public comment. The public comment period resulted in $>163$ comments from 38 individuals. The draft measurement set was also reviewed with a PD patient/caregiver panel in cooperation with the Parkinson's Foundation. The feedback received drove concept refinement.

The AAN plans to provide resources to review these measures every 6 months. AAN staff will conduct a literature search at this time interval for new guidelines, systematic reviews, or meta-analyses and will discuss implementation processes with organizations using quality measures to determine payment (such as the Medicare QPP). Any new data or implementation concerns will be forwarded to the work group to determine whether updates to the measurement set are necessary. Thus, this measure set should not be considered a long-term mandate but rather a working framework for measurement. The ultimate goal is to test the validity of these quality measures and whether they affect patient outcomes.

\section{Results}

Table 1 lists the titles and abbreviated details of the 10 measures approved for the final updated set. Full descriptions of these measures are available online in the full measurement set (aan.com/siteassets/home-page/policy-and-guidelines/ quality/quality-measures/movement-disorders/2020parkinson-disease-measurement-set-final.pdf).

After reviewing the 11 measures from the 2015 Parkinson's Disease Quality Measurement Set Update ${ }^{7}$ (table 2), the work 
Table 12020 Updated AAN Parkinson's Disease Measurement Set

\begin{tabular}{|c|c|c|c|c|}
\hline QM & Title & Numerator & Denominator & Exclusions \\
\hline 1 & $\begin{array}{l}\text { Annual Parkinson's Disease } \\
\text { Diagnosis Review }\end{array}$ & $\begin{array}{l}\text { Patients who had their diagnosis reviewed } \\
\text { annually for the first } 5 \text { y after initial diagnosis of } \\
\text { PD }\end{array}$ & $\begin{array}{l}\text { All patients with a } \\
\text { diagnosis of PD }\end{array}$ & None \\
\hline 2 & $\begin{array}{l}\text { Contraindicated Dopamine- } \\
\text { Blocking Medications }\end{array}$ & $\begin{array}{l}\text { Patients currently prescribed a contraindicated } \\
\text { dopamine-blocking agent }\end{array}$ & $\begin{array}{l}\text { All patients with a } \\
\text { diagnosis of PD }\end{array}$ & $\begin{array}{l}\text { Patients taking clozapine or quetiapine or } \\
\text { domperidone }\end{array}$ \\
\hline 3 & $\begin{array}{l}\text { Assessment of Parkinson's } \\
\text { Disease Medication-related } \\
\text { Motor Complications }\end{array}$ & $\begin{array}{l}\text { Patients who were assessed for dopaminergic } \\
\text { medication-related motor complications once } \\
\text { during the measurement period }\end{array}$ & $\begin{array}{l}\text { All patients with a } \\
\text { diagnosis of PD on a } \\
\text { dopaminergic medication }\end{array}$ & $\begin{array}{l}\text { Patients who are not able to participate in } \\
\text { assessment and no knowledgeable } \\
\text { informant available }\end{array}$ \\
\hline 4 & $\begin{array}{l}\text { Parkinson's Disease } \\
\text { Rehabilitative Therapy } \\
\text { Referral }\end{array}$ & $\begin{array}{l}\text { Patients who were referred to physical, } \\
\text { occupational, speech, or recreational therapy } \\
\text { once during the measurement period }\end{array}$ & $\begin{array}{l}\text { All patients with a } \\
\text { diagnosis of PD }\end{array}$ & $\begin{array}{l}\text { Patients and/or care partners decline } \\
\text { referral } \\
\text { Clinician determines patient does not } \\
\text { require referral } \\
\text { Patients already receiving physical, } \\
\text { occupational, speech, or recreational } \\
\text { therapy during the measurement period }\end{array}$ \\
\hline 5 & $\begin{array}{l}\text { Exercise or Physical Activity } \\
\text { Counseling }\end{array}$ & $\begin{array}{l}\text { Patients counseled on an exercise or physical } \\
\text { activity regimen once during the measurement } \\
\text { period }\end{array}$ & $\begin{array}{l}\text { All patients with a } \\
\text { diagnosis of PD }\end{array}$ & $\begin{array}{l}\text { Patients and/or care partners decline } \\
\text { counseling } \\
\text { Comorbid condition that deems the } \\
\text { patient unfit to participate in physical } \\
\text { activity } \\
\text { Patients who are not able to participate in } \\
\text { counseling and no knowledgeable } \\
\text { informant available }\end{array}$ \\
\hline 6 & $\begin{array}{l}\text { Assessment of Mood } \\
\text { Disorders and Psychosis }\end{array}$ & $\begin{array}{l}\text { Patients who were assessed for depression, } \\
\text { anxiety, apathy, and psychosis once during the } \\
\text { measurement period }\end{array}$ & $\begin{array}{l}\text { All patients with a } \\
\text { diagnosis of PD }\end{array}$ & None \\
\hline 7 & $\begin{array}{l}\text { Assessment of Impulse } \\
\text { Control Disorders }\end{array}$ & $\begin{array}{l}\text { Patients who were assessed for impulse } \\
\text { control disorder once during the measurement } \\
\text { period }\end{array}$ & $\begin{array}{l}\text { All patients with a } \\
\text { diagnosis of PD currently } \\
\text { taking medications for PD }\end{array}$ & None \\
\hline 8 & $\begin{array}{l}\text { Assessment of Sleep } \\
\text { Disturbances }\end{array}$ & $\begin{array}{l}\text { Patients who were assessed for sleep } \\
\text { disturbances once in the past } 12 \text { mo }\end{array}$ & $\begin{array}{l}\text { All patients with a } \\
\text { diagnosis of PD }\end{array}$ & None \\
\hline 9 & $\begin{array}{l}\text { Assessment of Cognitive } \\
\text { Impairment or Dysfunction }\end{array}$ & $\begin{array}{l}\text { Patients who were assessed for cognitive } \\
\text { impairment or dysfunction once in the past } 12 \\
\text { mo }\end{array}$ & $\begin{array}{l}\text { All patients with a } \\
\text { diagnosis of PD }\end{array}$ & $\begin{array}{l}\text { Patients and/or care partners decline } \\
\text { assessment } \\
\text { Patients who are not able to participate in } \\
\text { assessment and no knowledgeable } \\
\text { informant available }\end{array}$ \\
\hline 10 & $\begin{array}{l}\text { Assessment of Autonomic } \\
\text { Dysfunction }\end{array}$ & $\begin{array}{l}\text { Patients who were assessed for symptoms or } \\
\text { signs of autonomic dysfunction once in the } \\
\text { past } 12 \text { mo }\end{array}$ & $\begin{array}{l}\text { All patients with a } \\
\text { diagnosis of PD }\end{array}$ & None \\
\hline
\end{tabular}

Abbreviations: AAN = American Academy of Neurology; PD = Parkinson disease.

The above measures were approved by the work group. Providers are encouraged to identify the 1 or 2 measures that would be most meaningful for their patient populations and implement these measures to drive performance improvement in practice.

group voted to retire 2 of the measures (Fall Rate for Patients with Parkinson's Disease and Advanced Care Planning for Patients With Parkinson's Disease). A Falls Outcome measure and Advanced Care Planning measure now exist within the AAN Universal Neurology Quality Measurement Set, ${ }^{8}$ so retiring these measures reduces the number of disease-specific measures and harmonizes efforts between different AAN Quality Measurement Sets. The work group believes that Falls Outcomes and Advanced Care Planning are important topics to cover when caring for people with PD and recommends adopting the Falls Outcome and Plan of Care measure (aan. com/siteassets/home-page/policy-and-guidelines/quality/ quality-measures/other-neurologic-conditions/2018universalneurologymeasurementset.pdf) and the Advance Care Planning measure (aan.com/siteassets/home-page/policy- and-guidelines/quality/quality-measures/other-neurologicconditions/2018universalneurologymeasurementset.pdf) from the Universal Neurology Quality Measurement Set in addition to the 10 measures in the final PD Quality Measurement Set.

One of the previous measures, Psychiatric Symptoms Assessment for Patients With Parkinson's Disease, calculated the percentage of all patients with a diagnosis of $\mathrm{PD}$ who were assessed for psychiatric symptoms (psychosis, depression, anxiety disorder, apathy, and impulse control disorder) in the past 12 months. The work group voted to create a separate measure for impulse control disorders (Assessment of Impulse Control Disorders) that applies only to individuals with PD who take medications for their motor symptoms. The 
Table 2 Modifications to 2015 Parkinson's Disease Quality Measurement Set

\begin{tabular}{|c|}
\hline Annual Parkinson's Disease Diagnosis Review (updated) \\
\hline $\begin{array}{l}\text { Avoidance of Dopamine-Blocking Medications in Patients With } \\
\text { Parkinson's Disease (updated) }\end{array}$ \\
\hline $\begin{array}{l}\text { Psychiatric Symptoms Assessment for Patients With Parkinson's Disease } \\
\text { (split into } 2 \text { new measures) }\end{array}$ \\
\hline $\begin{array}{l}\text { Cognitive Impairment or Dysfunction Assessment for Patients With } \\
\text { Parkinson's Disease (updated) }\end{array}$ \\
\hline $\begin{array}{l}\text { Querying About Symptoms of Autonomic Dysfunction for Patients With } \\
\text { Parkinson's Disease (updated) }\end{array}$ \\
\hline $\begin{array}{l}\text { Querying About Sleep Disturbances for Patients With Parkinson's Disease } \\
\text { (updated) }\end{array}$ \\
\hline Fall Rate for Patients With Parkinson's Disease (retired) ${ }^{a}$ \\
\hline Parkinson's Rehabilitative Therapy Options (updated) \\
\hline $\begin{array}{l}\text { Counseling Patients With Parkinson's Disease About Regular Exercise } \\
\text { Regimen (updated) }\end{array}$ \\
\hline $\begin{array}{l}\text { Querying About Parkinson's Disease Medication-Related Motor } \\
\text { Complications (updated) }\end{array}$ \\
\hline Advanced Care Planning for Patients With Parkinson's Disease (retired) ${ }^{a}$ \\
\hline $\begin{array}{l}\text { Measures have been retired for the } 2020 \text { update, and the work group } \\
\text { ecommends adopting the } 2 \text { related measures (Falls Outcome and Plan of } \\
\text { are; Advance Care Planning) from the Universal Neurology Quality Mea- } \\
\text { urement Set. }\end{array}$ \\
\hline
\end{tabular}

other psychiatric symptoms in the previous measure are now grouped under Assessment of Mood Disorders and Psychosis and will continue to apply to everyone with a diagnosis of PD, regardless of treatment status.

The work group updated the other 8 measures from the 2015 PD measurement set. In general, these updates included (1) consistent language throughout (using the term assessment as opposed to both assessment and querying), (2) simplification of the measure titles, (3) technical updates of measure specifications (numerators, denominators, exclusions, time frame, and care settings), (4) development of key words that would endorse implementation in quality registries, and (5) promotion of the use of validated scales or instruments to satisfy the measures. Given the rapid global implementation of teleneurology due to the coronavirus disease 2019 (COVID-19) pandemic, ${ }^{14,15}$ telehealth visits were added to the care settings for all measures. Additional specific changes in this update are detailed later in this article.

The work group considered several new measure proposals for this update. Some overlapped with existing measures and were not developed further. Other novel proposals, including those related to caregiver burden/quality of life, ability to manage medications, driving, and ability to carry out activities of daily living/instrumental activities of daily living, were discussed and debated by the work group. In deciding whether to adopt these measures, we considered many factors, including the strength of existing evidence, the presence of clinical practice guidelines, and the ease of implementing and tracking the measure. Unfortunately, none of these novel measures gained enough support for inclusion in the current set. These concepts may be revisited at the time of the next measurement set update.

\section{Annual Parkinson's Disease Diagnosis Review}

The work group felt that an annual diagnosis review measure was important to keep because of implications on prognosis and optimization of therapy. The Annual Parkinson's Disease Diagnosis Review measures the percentage of patients who had their diagnosis reviewed annually, with a review defined as use of the UK Parkinson's Disease Society Brain Bank Clinical Diagnostic Criteria, ${ }^{16}$ Movement Disorder Society (MDS) Clinical Diagnostic Criteria for $\mathrm{PD},{ }^{17}$ or a discussion of differential diagnosis. Historically, this measure has had the lowest compliance rate of the entire set, ranging from $14.3 \%$ to $29 \% .^{11,12}$ To reduce the documentation burden for clinicians and to improve compliance, the work group voted to apply this measure for only the first 5 years after PD diagnosis. This time period was chosen because most of the red flags listed in the MDS Clinical Diagnostic Criteria for PD use 5 years as a cutoff (i.e., rapid progression of gait or bulbar dysfunction within 5 years of onset). ${ }^{17}$ While a small proportion of patients could still have an incorrect diagnosis beyond 5 years, diagnostic accuracy of PD improves with longer-term follow-up, ${ }^{18}$ so the work group felt this was a compromise that would not unreasonably sacrifice quality of care.

\section{Contraindicated Dopamine- Blocking Medications}

This measure was introduced in the 2015 measurement update as Avoidance of Dopamine-Blocking Medications in Patients With Parkinson's Disease. ${ }^{7}$ The prescription of dopamine-blocking agents continues to be a problem; a recent study using 2014 Medicare data showed that $8.7 \%$ of beneficiaries with PD filled prescription for a medication that could worsen their motor symptoms. ${ }^{19}$ The title change more accurately reflects what is being measured: the percentage of patients with PD on a contraindicated dopamine-blocking agent. The numerator list was updated with additional antipsychotic agents. Domperidone, a peripherally acting dopamine antagonist commonly used to treat gastrointestinal symptoms in PD, was added as an exclusionary medication.

\section{Assessment of Parkinson Disease Medication-Related Motor Complications}

The majority of people with PD eventually develop motor complications ("off" states and dyskinesias) from levodopa therapy. By measuring how frequently providers assess these complications, we anticipate that optimization of medications will occur and referral for surgical or device-assisted therapies will increase. However, neurologists still frequently fail to recognize "off" phenomena. ${ }^{20}$ The 2013 study by Baek et al. ${ }^{11}$ 
reviewing compliance with quality measure recommendations noted a $23.5 \%$ provider compliance rate for this measure. In a tertiary movement disorders clinic, the compliance rate for this measure was better (77\%) but still leaves room for improvement. ${ }^{12}$ To improve compliance, the work group voted to change the assessment frequency to once a year rather than at every visit. This makes the assessment interval consistent with the other measures. We also provided some wearing-off scales as options to help busy clinicians recognize "off" phenomena.

\section{Assessment of Mood Disorders and Psychosis}

There has been no change in the importance of nonmotor symptoms affecting the quality of life in PD since the last measurement update. Therefore, the work group voted to keep all measures assessing nonmotor symptoms. As mentioned, the Psychiatric Symptoms Assessment for Patients With Parkinson's Disease was split into 2 measures: Assessment of Mood Disorders and Psychosis and Assessment of Impulse Control Disorders. The Assessment of Mood Disorders and Psychosis measure calculates the percentage of all patients with a diagnosis of PD who were assessed for depression, anxiety, apathy, and psychosis annually. Documentation of all 4 disorders is necessary to satisfy the measure, reflecting the work group's view that all of these disorders are important. Although a study from Martello et al. ${ }^{12}$ reported that documentation of this measure in a movement disorders center was at $90 \%$, compliance consisted of documentation of only 1 of the psychiatric disorders. Therefore, there is an opportunity for improvement in assessing all 4 disorders. Because either a discussion with the patient or the use of a rating scale counts as assessment, the work group also suggested additional rating scales for use.

\section{Assessment of Impulse Control Disorders}

This measure specifies assessing the presence of an impulse control disorder (gambling, hypersexual activity, binge eating, increased spending, dopamine dysregulation, repetitive behaviors, punding) annually. Impulse control disorders have a cumulative 5-year incidence of $46.1 \%,{ }^{21}$ and the work group felt that this disorder required a separate measure because of the potential devastating consequences if not identified early. Because of the strong association between impulse control disorders and PD medications, ${ }^{22}$ this measure applies to visits for people with PD who are already on or will soon initiate treatment for their motor symptoms.

\section{Parkinson Disease Rehabilitative Therapy Referral/Exercise or Physical Activity Counseling/Assessment of Sleep Disturbances/ Assessment of Cognitive Impairment or Dysfunction/Assessment of Autonomic Dysfunction}

The work group kept these 5 measures largely intact with only minor changes to make the titles and language consistent with other measures. For the exercise measure, the work group added yoga to the list as an example of an acceptable form of exercise. ${ }^{23}$ There is insufficient evidence currently to promote 1 specific type of exercise over another. Because sleep disturbances, cognitive impairment, and autonomic dysfunction manifest in several different ways, the measures use specific terms to help ease documentation for clinicians. The work group added 2 terms to the sleep disturbances list (sleep disordered breathing, circadian rhythm disorders) and 2 terms to the cognitive impairment list (poor attention, concentration). The list of applicable screening instruments for both sleep disturbances and cognitive impairment was updated.

\section{Conclusions}

The measures presented here represent the second update of the PD Quality Measurement Set. The overarching goal of the work group was to decrease documentation burden without sacrificing quality. We also made it easier to assess compliance with many of these measures by providing key words that can be searched in the medical record. Finally, we aligned this set with the recently published Universal Neurology Quality Measurement Set. The process has resulted in 10 diseasespecific PD measures and 2 recommended measures from the Universal Neurology set (Falls Outcome and Plan of Care and Advance Care Planning).

All of the measures in this measurement set are process measures. Process measures "focus on actions of health care professionals and evaluate whether these activities follow established evidence-based clinical guidelines, care protocols and best practices." 24 Thus, they operationalize existing guidelines for use in clinical practice, not the other way around. During the public comment period, the work group received feedback to include driving and care partner burden/ quality of life in the measurement set. Unfortunately, because there were no evidence-based clinical practice guidelines available for these topics, the work group was unable to support such measures at this time. These issues reflect current gaps in the literature, and the work group hopes that there will be more advances by the time of the next update.

The relationship between documentation of process measures and actual outcomes is currently unknown. The University of Maryland study did not find a correlation between adherence to quality measures and patient outcomes 1 year after the visit, including death, number of follow-up or emergency department visits, phone calls, referrals, nursing home placement, or ratings in quality of life, disability, or disease severity. ${ }^{12}$ The International Consortium for Health Outcomes Measurement has developed a consensus set of outcomes for PD, which include the MDS-Unified Parkinson's Disease Rating Scale parts 1 and 2, 3 questions from the NMSQuest, the Parkinson's Disease Questionnaire-8, and 6 questions from the Dutch National PD registry. ${ }^{25}$ Aspects of the National Institute of Neurological Disorders and Stroke PD Common Data Elements Set could also be considered as 
outcome measurements. However, studies are necessary to validate the usefulness of these particular scales/instruments in this context. Because the Centers for Medicare \& Medicaid Services intends to shift the quality measures included in the QPP MIPS to outcome measures, ${ }^{26}$ future updates to this measurement set will need to focus on generating appropriate outcome measures. In the meantime, the updates presented here should enhance compliance and drive improvement in the quality of care for individuals with PD.

\section{Study Funding}

The authors report no targeted funding

\section{Disclosure}

K. Chou received funding for travel from CNS Ratings, Sunovion Pharmaceuticals, and Inventram; serves on the Neurology editorial board, NPJ Parkinson's Disease editorial board, and Parkinsonism and Related Disorders editorial board; Receives royalties from publishing from Springer Deep Brain Stimulation: A New Life for Patient's with Parkinson Disease, Essential Tremor and Dystonia, Essential Tremor in Clinical Practice, and UpToDate; received honoraria from Accordant, CNS Ratings, Watermark Research Partners, Sunovion Pharmaceuticals, and Inventram; and receives research support from Eli Lilly, Parkinson Study Group, Voyager Therapeutics, and NIH. J. Martello received personal compensation for consulting on a scientific advisory speaking board, speaking, or other activities with Neurocrine, Medtronic, Teva, Abbvie, and Lundbeck. J. Atem and M. Elrod report no disclosures relevant to the manuscript. E. Foster receives research support from NIH, the Greater St. Louis Chapter of the American Parkinson Disease Association (APDA), and the APDA Center for Advanced PD Research at Washington University School of Medicine in St. Louis. K. Freshwater reports no disclosures relevant to the manuscript. S. Gunzler receives research support from NIH, Impax, Biogen, and the Parkinson Study Group. H. Kim received funding for travel and honoraria from Cleveland Clinic. A. Mahajan received funding from the Dystonia Medical Research Foundation, Sunflower Parkinson's Disease Foundation, and Parkinson's Foundation outside of the submitted work. He reports no conflicts of interest. H. Sarva received honoraria from the Edmond J. Safra Foundation and research support from Michael J. Fox Foundation. She has received research support from Lundbeck, Intec, Insightec, Biogen, Covance, and Syneos for her role as clinical trial investigator. She has also served as consultant for Accorda, Amneal, Merz, and Neurocrine. She has received internal Cornell funding. G. Stebbins serves on a scientific advisory board for Acadia Pharmaceuticals, Adamas Pharmaceuticals Inc, Biogen, Ceregene, CHDI Management, Cleveland Clinic Foundation, Ingenix Pharmaceutical Services, MedGenesis Therapeutix, Neurocrine Biosciences, Pfizer, Tools-4 Patients, Ultragenyx, and Sunshine Care Foundation; received funding for travel from NIH, Michael J. Fox Foundation, Dystonia Coalition, CHDI, International Parkinson and Movement Disorder Society, and Alzheimer's Association; received honoraria from International Parkinson and Movement Disorder Society, American Academy of Neurology, Michael J. Fox Foundation, Food and Drug Administration, NIH, and Alzheimer's Association; and receives research support from NIH, Department of Defense, Michael J. Fox Foundation, Dystonia Coalition, Cleveland Clinic Foundation, International Parkinson and Movement Disorder Society, and CBD Solutions. E. Lee reports no disclosures relevant to the manuscript. L. Yang serves on a scientific advisory board for Acacia Pharmaceuticals; receives research funding from Biogen, Alzheimer's Disease Research Center, Udall, and the Michael J. Fox Foundation; and holds stock or stock options with Teva and Nvidia. Go to Neurology.org/N for full disclosures.

\section{Publication History}

Received by Neurology November 17, 2020. Accepted in final form April 7, 2021.

Appendix Authors

\begin{tabular}{|c|c|c|}
\hline Name & Location & Contribution \\
\hline $\begin{array}{l}\text { Kelvin Chou, } \\
\text { MD }\end{array}$ & $\begin{array}{l}\text { University of Michigan } \\
\text { Medical School, Ann Arbor }\end{array}$ & $\begin{array}{l}\text { Study concept and design, } \\
\text { acquisition of data, analysis } \\
\text { and/or interpretation of data, } \\
\text { drafting/revising the } \\
\text { manuscript, critical revisions } \\
\text { of the manuscript for } \\
\text { important intellectual } \\
\text { content, and study } \\
\text { supervision including } \\
\text { responsibility for conduct of } \\
\text { research and final approval }\end{array}$ \\
\hline
\end{tabular}

Justin Christiana Care, Wilmington, Study concept and design,

Martello, DE

MD and/or interpretation of data, drafting/revising the manuscript, critical revisions of the manuscript for important intellectual content, and study supervision including responsibility for conduct of research and final approval

\begin{tabular}{lll}
\hline Juliana & UT Southwestern Medical & Acquisition of data, analysis \\
Atem, MSN, Center, Dallas, TX & and/or interpretation of data, \\
APRN & drafting/revising the \\
& manuscript, critical revisions \\
& of the manuscript for \\
important intellectual & content
\end{tabular}

Matt Elrod, MaxMD, Fort Lee, NJ Acquisition of data, analysis DPT and/or interpretation of data, drafting/revising the manuscript, critical revisions of the manuscript for important intellectual content

\begin{tabular}{lll}
\hline $\begin{array}{l}\text { Erin R. } \\
\begin{array}{l}\text { Foster, PhD, } \\
\text { OTD, OTR/L }\end{array} \\
\text { MO }\end{array}$ & $\begin{array}{l}\text { Acquisition of data, analysis } \\
\text { and/or interpretation of data, }\end{array}$ \\
& $\begin{array}{l}\text { Bronson Neuroscience } \\
\text { drafting/revising the } \\
\text { manuscript, critical revisions } \\
\text { of the manuscript for } \\
\text { important intellectual } \\
\text { content }\end{array}$ \\
$\begin{array}{l}\text { Karen } \\
\text { PA-C }\end{array}$ & $\begin{array}{l}\text { Acquisition of data, analysis } \\
\text { and/orinterpretation of data, } \\
\text { drafting/revising the } \\
\text { manuscript, critical revisions } \\
\text { of the manuscript for }\end{array}$ \\
& & $\begin{array}{l}\text { important intellectual } \\
\text { content }\end{array}$ \\
\hline
\end{tabular}


Appendix (continued)

\begin{tabular}{lll}
\hline Name & Location & Contribution \\
\hline $\begin{array}{l}\text { Steven A. } \\
\text { Gunzler, MD }\end{array}$ & $\begin{array}{l}\text { University Hospitals } \\
\text { Cleveland Medical Center } \\
\text { and Case Western Reserve } \\
\text { University, OH }\end{array}$ & $\begin{array}{l}\text { Acquisition of data, analysis } \\
\text { and/or interpretation of data, } \\
\text { drafting/revising the } \\
\text { manuscript, critical revisions } \\
\text { of the manuscript for } \\
\text { important intellectual } \\
\text { content }\end{array}$ \\
\hline Hojoong & $\begin{array}{ll}\text { Veterans Affairs Puget } \\
\text { Kim, MD }\end{array}$ & $\begin{array}{l}\text { Scquisition of data, analysis } \\
\text { and/or interpretation of data, } \\
\text { drafting/revising the } \\
\text { Seattle, WA }\end{array}$ \\
& & $\begin{array}{l}\text { manuscript, critical revisions } \\
\text { of the manuscript for } \\
\text { important intellectual } \\
\text { content }\end{array}$ \\
& &
\end{tabular}

Department of Neurology,

University of Washington

School of Medicine, Seattle

\begin{tabular}{ll}
\hline Abhimanyu & Rush University Medical \\
Mahajan, & Center, Chicago, IL \\
MD, MHS &
\end{tabular}

Acquisition of data, analysis and/or interpretation of data, drafting/revising the manuscript, critical revisions of the manuscript for important intellectual content

\begin{tabular}{ll}
\hline Harini & Weill Cornell Medicine, New \\
Sarva, MD & York, NY
\end{tabular}

Acquisition of data, analysis and/or interpretation of data, drafting/revising the manuscript, critical revisions of the manuscript for important intellectual content

Glenn T.
Stebbins,
PhD

Acquisition of data, analysis and/or interpretation of data, drafting/revising the manuscript, critical revisions of the manuscript for important intellectual content

Erin Lee American Academy of Study concept and design,
Neurology, Minneapolis, MN acquisition of data, analysis and/or interpretation of data, drafting/revising the manuscript, critical revisions of the manuscript for important intellectual content, and study supervision including responsibility for conduct of research and final approval

\begin{tabular}{ll}
\hline Laurice & Stanford Health Care, Palo \\
Yang, MD, & Alto, CA \\
MHA &
\end{tabular}

Study concept and design, acquisition of data, analysis and/or interpretation of data, drafting/revising the manuscript, critical revisions of the manuscript for important intellectual content, and study supervision including responsibility for conduct of research and final approval

\section{References}

1. Ascherio A, Schwarzschild MA. The epidemiology of Parkinson's disease: risk factors and prevention. Lancet Neurol. 2016;15(12):1257-1272.

2. GBD 2015 Neurological Disorders Collaborator Group. Global, regional, and national burden of neurological disorders during 1990-2015: a systematic analysis for the Global Burden of Disease Study 2015. Lancet Neurol. 2017; 16(11):877-897.

3. GBD 2016 Parkinson's Disease Collaborators. Global, regional, and national burden of Parkinson's disease, 1990-2016: a systematic analysis for the Global Burden of Disease Study 2016. Lancet Neurol. 2018;17(11):939-953.

4. Marras C, Beck JC, Bower JH, et al. Prevalence of Parkinson's disease across North America. NPJ Parkinsons Dis. 2018;4(1):21.

5. Kuhlman GD, Flanigan JL, Sperling SA, Barrett MJ. Predictors of healthrelated quality of life in Parkinson's disease. Parkinsonism Relat Disord. 2019; 65:86-90.

6. Cheng EM, Tonn S, Swain-Eng R, et al. Quality improvement in neurology: AAN Parkinson disease quality measures: report of the Quality Measurement and Reporting Subcommittee of the American Academy of Neurology. Neurology. 2010; 75(22):2021-2027.

7. Factor SA, Bennett A, Hohler AD, Wang D, Miyasaki JM. Quality improvement in neurology: Parkinson Disease Update Quality Measurement Set: executive summary. Neurology. 2016;86(24):2278-2283.

8. Martello J, Buchhalter J, Das RR, et al. Quality improvement in neurology: Universal Neurology Quality Measurement Set: executive summary. Neurology. 2019;92(9) 418-426.

9. Willis AW, Schootman M, Tran R, et al. Neurologist-associated reduction in PDrelated hospitalizations and health care expenditures. Neurology. 2012;79(17): 1774-1780.

10. Willis AW, Schootman M, Evanoff BA, Perlmutter JS, Racette BA. Neurologist care in Parkinson disease: a utilization, outcomes, and survival study. Neurology. 2011;77(9): 851-857.

11. Baek WS, Swenseid SS, Poon KY. Quality care assessment of Parkinson's disease at a tertiary medical center. Int J Neurosci. 2013;123(4):221-225.

12. Martello J, Shulman LM, Barr E, Gruber-Baldini A, Armstrong MJ. Assessment of Parkinson disease quality measures on 12-month patient outcomes. Neurol Clin Pract. 2020;10(1):58-64.

13. Vaughan CP, Prizer LP, Vandenberg AE, et al. A comprehensive approach to care in Parkinson's disease adds quality to the current gold standard. Mov Disord Clin Pract. 2017;4(5):743-749.

14. Yang L, Brown-Johnson CG, Miller-Kuhlmann R, et al. Accelerated launch of video visits in ambulatory neurology during COVID-19: key lessons from the Stanford experience. Neurology. 2020;95(7):305-311.

15. Grossman SN, Han SC, Balcer LJ, et al. Rapid implementation of virtual neurology in response to the COVID-19 pandemic. Neurology. 2020;94(24):1077-1087.

16. Hughes AJ, Daniel SE, Kilford L, Lees AJ. Accuracy of clinical diagnosis of idiopathic Parkinson's disease: a clinico-pathological study of 100 cases. J Neurol Neurosurg Psychiatry. 1992;55(3):181-184.

17. Postuma RB, Berg D, Stern M, et al. MDS clinical diagnostic criteria for Parkinson's disease. Mov Disord. 2015;30(12):1591-1601.

18. Adler CH, Beach TG, Hentz JG, et al. Low clinical diagnostic accuracy of early vs advanced Parkinson disease: clinicopathologic study. Neurology. 2014;83(9): 406-412.

19. Abraham DS, Pham Nguyen TP, Hennessy S, et al. Frequency of and risk factors for potentially inappropriate medication use in Parkinson's disease. Age Ageing. 2020; 49(5):786-792.

20. Chou KL, Stacy M, Simuni T, et al. The spectrum of "off" in Parkinson's disease: what have we learned over 40 years?. Parkinsonism Relat Disord. 2018;51(7):9-16.

21. Corvol JC, Artaud F, Cormier-Dequaire F, et al. Longitudinal analysis of impulse control disorders in Parkinson disease. Neurology. 2018;91(3):e189-e201.

22. Eisinger RS, Ramirez-Zamora A, Carbunaru S, et al. Medications, deep brain stimulation, and other factors influencing impulse control disorders in Parkinson's disease. Front Neurol. 2019;10:86.

23. Deuel LM, Seeberger LC. Complementary therapies in Parkinson disease: a review of acupuncture, Tai Chi, Qi Gong, yoga, and cannabis. Neurotherapeutics. 2020;17(4): 1434-1455

24. American Academy of Neurology Parkinson Disease Quality Measurement Manual 2019 Update. Available at: aan.com/policy-and-guidelines/quality/quality-measures2/ how-measures-are-developed/. Accessed March 3, 2020.

25. de Roos P, Bloem BR, Kelley TA, et al. A consensus set of outcomes for Parkinson's disease from the International Consortium for Health Outcomes Measurement. J Parkinsons Dis. 2017;7(3):533-543.

26. Sico JJ, Sarwal A, Benish SM, et al. Quality improvement in neurology: Neurology Outcomes Quality Measurement Set. Neurology. 2020;94(22):982-990. 


\section{Neurology}

\section{Quality Improvement in Neurology: 2020 Parkinson Disease Quality Measurement Set Update}

Kelvin L. Chou, Justin Martello, Juliana Atem, et al. Neurology 2021;97;239-245

DOI 10.1212/WNL.0000000000012198

This information is current as of August 2, 2021

$\begin{array}{ll}\begin{array}{l}\text { Updated Information \& } \\ \text { Services }\end{array} & \begin{array}{l}\text { including high resolution figures, can be found at: } \\ \text { http://n.neurology.org/content/97/5/239.full }\end{array} \\ \text { References } & \text { This article cites } 25 \text { articles, } 11 \text { of which you can access for free at: } \\ & \text { http://n.neurology.org/content/97/5/239.full\#ref-list-1 } \\ \text { Subspecialty Collections } & \text { This article, along with others on similar topics, appears in the } \\ & \text { following collection(s): } \\ & \text { All Health Services Research } \\ & \text { http://n.neurology.org/cgi/collection/all_health_services_research } \\ & \text { All Practice Management } \\ \text { http://n.neurology.org/cgi/collection/all_practice_management } & \text { Parkinson's disease/Parkinsonism } \\ & \text { http://n.neurology.org/cgi/collection/parkinsons_disease_parkinsonism } \\ & \text { Information about reproducing this article in parts (figures,tables) or in } \\ & \text { its entirety can be found online at: } \\ \text { http://www.neurology.org/about/about_the_journal\#permissions } & \text { Information about ordering reprints can be found online: } \\ \text { Permissions \& Licensing } & \text { http://n.neurology.org/subscribers/advertise }\end{array}$

Neurology ${ }^{\circledR}$ is the official journal of the American Academy of Neurology. Published continuously since 1951, it is now a weekly with 48 issues per year. Copyright @ 2021 American Academy of Neurology. All rights reserved. Print ISSN: 0028-3878. Online ISSN: 1526-632X.

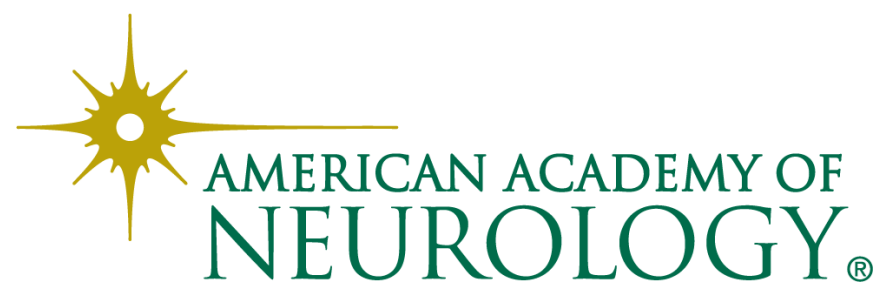

